\title{
EFFECTS OF ISOPROTERENOL ON PERIPHERAL VENOUS TONE AND TRANSMURAL RIGHT ATRIAL PRESSURE IN MAN *
}

\author{
By JOHN W. ECKSTEIN $†$ AND WILLIAM K. HAMILTON \\ (From the Hemodynamic Laboratory, Cardiovascular Research Laboratories, Department of \\ Internal Medicine, and the Division of Anesthesiology, Department of Surgery, \\ State University of Iowa College of Medicine, Iowa City, Iowa)
}

(Submitted for publication August 15, 1958, accepted October 16, 1958)

The increase in cardiac output during isoproterenol administration has been attributed to a direct action on the heart causing it to extract blood more effectively from the central venous reservoir (1). Another suggestion is that isoproterenol constricts peripheral veins and causes blood to be pushed into the heart (2). The observation that right atrial pressure falls during infusion of the drug (3) would seem to dispose of the latter explanation. Right atrial pressure, measured with respect to atmospheric pressure, however, is not the force which distends the atrium. The pressure which actually distends the atrium, the transmural pressure, is the difference between the pressure within the chamber and the intrapleural pressure which surrounds it. Transmural atrial pressure, then, may be influenced by changes in intrapleural pressure.

In previous studies (4) we found that hyperventilation causes transmural atrial pressure to rise even though atrial pressure falls. This occurs because overbreathing is associated with a greater reduction in intrapleural pressure than in right atrial pressure. Isoproterenol, like epinephrine, appears to cause central excitation (5). It is known that epinephrine causes hyperventilation (6), probably by a central excitatory action. If isoproterenol has a similar effect on breathing, the fall it produces in right atrial pressure could be a ventilatory effect. If this were true the fall in atrial pressure might not indicate a coincident fall in transmural pressure.

If isoproterenol causes blood to be pushed centrally, peripheral venous constriction would have to provide the "pushing" force. To our knowl-

\footnotetext{
* Supported by a research grant (H-2644) from the National Heart Institute of the Public Health Service, and aided by a grant from the Iowa Heart Association.

$\dagger$ Established Investigator of the American Heart Association.
}

edge no observations on the peripheral venous responses to isoproterenol have been reported. Since epinephrine causes venous constriction in the forearm (7) and since some actions of isoproterenol on the vascular system are different from those of epinephrine (5), the matter of isoproterenol causing venous constriction and a shift of blood from the periphery of the body needs investigation.

This report concerns experiments which were done to see what happens to peripheral venomotor tone and transmural right atrial pressure during isoproterenol administration.

\section{METHODS AND PROCEDURES}

The experiments were performed on 10 healthy male medical students. In the first group of five experiments subjects were studied in the right lateral decubitus position with the right arm extended downward through a hole in the table. Right atrial pressure was measured with a Statham 0 to $5 \mathrm{~cm}$. $\mathrm{Hg}$ strain gage connected to a needle in the antecubital vein of the dependent arm according to the method of Gauer and Sieker (8). Intrapleural pressure was measured as esophageal pressure with a Statham 0 to $5 \mathrm{~cm}$. $\mathrm{Hg}$ strain gage connected to a small, open-ended, water-filled polyethylene tube. The tip was placed in the lower third of the esophagus. Esophageal pressure is similar to but not identical with intrapleural pressure. Changes in the two tend to be parallel (9), however, so that esophageal pressure changes reflect changes in intrapleural pressure. The difference between right atrial and esophageal pressure, the transmural right atrial pressure, was measured with a Sanborn differential pressure transducer. End-expiratory $\mathrm{CO}_{2}$ concentration was monitored with a Liston-Becker $\mathrm{CO}_{2}$ analyzer and ventilation was measured with a gas meter (10). All three pressures and $\mathrm{CO}_{2}$ concentration were recorded simultaneously with a Sanborn directwriting oscillograph.

After control values were established isoproterenol chloride ${ }^{1}$ was infused into a foot vein at a constant rate of $5.8 \mu \mathrm{g}$. per minute. Experimental observations were made after the pressures had been stable for at least 45

${ }^{1}$ Isupre1 ${ }^{\circledR}$, Winthrop Laboratories, New York, N. Y. 
seconds. In most cases the measurements were made 90 to 120 seconds after the infusion was started. The infusion usually was discontinued as soon as the experimental measurements were obtained. Observations were continued until control values returned. Reported mean pressures were obtained by counting squares under the curves registered by electrical integration of the output of the manometers. The sensitivity of the amplifying system was adjusted so that respiratory pressure changes when integrated electrically occupied at least 2 to $3 \mathrm{~cm}$. on the recording paper. In most experiments $1 \mathrm{~cm}$. vertically on the recording paper was equal to 2.0 or 5.0 $\mathrm{mm}$. $\mathrm{Hg}$. Pressures were read to the nearest $0.5 \mathrm{~mm}$. $\mathrm{Hg}$.

In the second group of five experiments the subjects were studied in the supine position. Forearm venous pressure-volume curves were obtained by a modification (11) of the plethysmographic method of Litter, Wood and Wilkins $(12,13)$. Forearm volume changes were measured by means of two partially immersed electrodes (14) which sensed changes in the height of the water in a vertical cylinder attached to the top of the plethysmograph. Except for this change in the measurement of volume the pressure-volume curves were obtained as in previous experiments with epinephrine (7). Forearm venous pressure was measured in the antecubital vein of the arm unencumbered by the plethysmograph. In all experiments the arm in which venous pressure was measured was below atrial level. Curves and venous pressure measurements were obtained before, during and after isoproterenol infusion into a foot vein as in the first group of experiments.

Following the experiments, venous pressure-volume curves were constructed. These curves (Figure 1) express in $\mathrm{ml}$. per $100 \mathrm{ml}$. of forearm tissue the volume to which the veins are distended by any level of transmural venous pressure between 0 and $30 \mathrm{~mm}$. $\mathrm{Hg}$. The final point on the curve, the venous volume at $30 \mathrm{~mm} . \mathrm{Hg}$, is called arbitrarily the venous distensibility. A high value represents venous dilatation and a low value venous constriction. Assuming that the venous pressure-volume characteristics are the same in both arms, the naturally occurring venous volume of the forearm is the volume coordinate of that point on the curve which corresponds to the natural venous pressure (equals transmural venous pressure) measured in the arm opposite the one in the plethysmograph. The venous volume existing during each measurement of distensibility was determined by drawing a line perpendicular to the pressure axis from the natural venous pressure value (Figure 1). If a stimulus such as isoproterenol produces venous constriction and also a fall in venous pressure, the decrease in volume caused by each of these factors alone may be determined. The volume coordinate of the point on the isoproterenol curve which corresponds to the control venous pressure is the venous volume which would have existed had the total volume reduction been caused by venous constriction alone. The difference between this value and the venous volume which existed during the stimulus

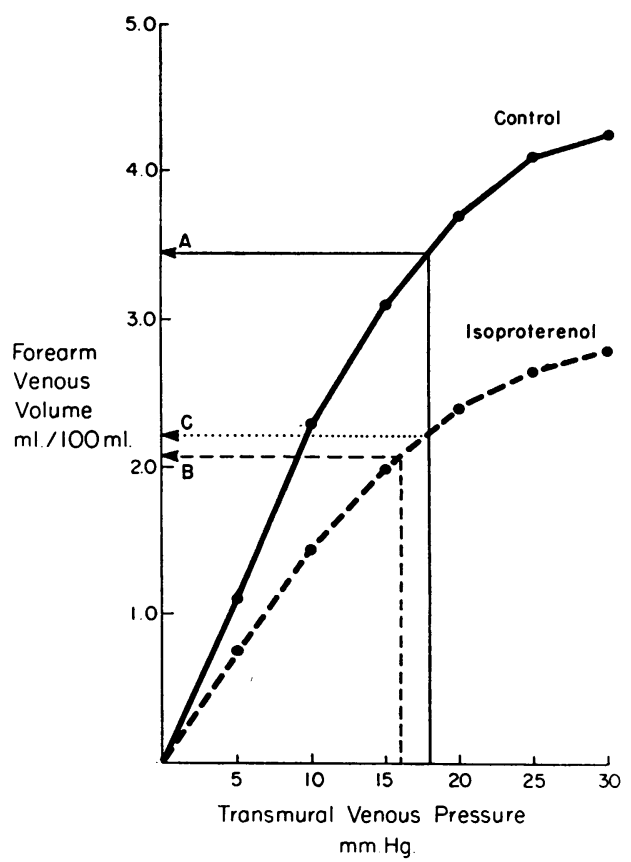

Fig. 1. Venous Pressure-Volume Curves

(EXPERIMENT 3)

A refers to the forearm venous volume which existed during the control period. B refers to the volume during isoproterenol infusion. $C$ refers to the volume which would have existed during isoproterenol infusion if there had been only venous constriction and no change in venous pressure.

represents the reduction in venous volume caused by the fall in venous pressure alone.

Statistical analysis of the data was carried out according to methods described by Fisher (15).

\section{RESULTS}

Effect of isoproterenol on end-expiratory $\mathrm{CO}_{2}$ tension and ventilation

Ventilation increased in each of five experiments during isoproterenol infusion (Table I). The average increase was 8.0 L. per min. ( $p<$ $0.01)$. End-expiratory $\mathrm{CO}_{2}$ tension decreased in each experiment. The average decrease was 5.8 mm. Hg $(\mathrm{p}<0.01)$.

\section{Effect of isoproterenol on transmural right atrial pressure}

Despite the hyperventilation no consistent changes were observed in mean esophageal pressure. It increased in two, decreased in one and remained unchanged in two of the five experiments 
TABLE I

Transmural right atrial pressure responses to isoproterenol infusion

\begin{tabular}{|c|c|c|c|c|c|c|c|c|c|c|}
\hline \multirow[b]{2}{*}{$\begin{array}{l}\text { Experi- } \\
\text { ment }\end{array}$} & \multicolumn{2}{|c|}{ Esophageal pressure } & \multicolumn{2}{|c|}{ Atrial pressure } & \multicolumn{2}{|c|}{$\begin{array}{c}\text { Transmural atrial } \\
\text { pressure }\end{array}$} & \multicolumn{2}{|c|}{$\begin{array}{l}\text { End-expiratory } \\
\mathrm{CO}_{2} \text { tension }\end{array}$} & \multicolumn{2}{|c|}{ Ventilation } \\
\hline & Control & $\begin{array}{c}\text { Iso- } \\
\text { proterenol }\end{array}$ & Control & $\begin{array}{l}\text { Iso- } \\
\text { proterenol }\end{array}$ & Control & $\begin{array}{l}\text { Iso- } \\
\text { proterenol }\end{array}$ & Control & $\begin{array}{l}\text { Iso- } \\
\text { proterenol }\end{array}$ & Control & $\begin{array}{l}\text { Iso- } \\
\text { proterenol }\end{array}$ \\
\hline no. & \multicolumn{2}{|c|}{$m m . \mathrm{Hg}$} & \multicolumn{2}{|c|}{$m m . H_{g}$} & \multicolumn{2}{|c|}{$m m . H g$} & \multicolumn{2}{|c|}{$m m . H g$} & \multicolumn{2}{|c|}{ L./min. } \\
\hline $\begin{array}{l}1 \\
2 \\
3 \\
4 \\
5\end{array}$ & $\begin{array}{l}-7.0 \\
-7.0 \\
-2.5 \\
-7.5 \\
-8.0\end{array}$ & $\begin{array}{l}-6.0 \\
-7.0 \\
-2.5 \\
-9.5 \\
-7.0\end{array}$ & $\begin{array}{r}4.0 \\
3.0 \\
-0.5 \\
4.5 \\
3.0\end{array}$ & $\begin{array}{r}3.0 \\
2.0 \\
-3.0 \\
1.0 \\
1.5\end{array}$ & $\begin{array}{r}11.5 \\
9.0 \\
2.5 \\
12.5 \\
11.0\end{array}$ & $\begin{array}{r}9.5 \\
8.5 \\
-0.5 \\
11.5 \\
8.0\end{array}$ & $\begin{array}{l}42.0 \\
36.2 \\
43.0 \\
45.8 \\
42.3\end{array}$ & $\begin{array}{l}38.1 \\
33.2 \\
34.0 \\
39.5 \\
35.6\end{array}$ & $\begin{array}{l}6.6 \\
4.1 \\
7.5 \\
6.8 \\
4.1\end{array}$ & $\begin{array}{l}11.1 \\
13.6 \\
14.7 \\
18.8 \\
10.8\end{array}$ \\
\hline $\begin{array}{l}\text { Mean difference } \\
\text { Standard error } \\
\text { Probability }\end{array}$ & & $\begin{array}{l}0.0 \\
0.55 \\
>0.9\end{array}$ & & $\begin{array}{r}1.9 \\
0.48 \\
<0.02\end{array}$ & . & $\begin{array}{r}1.9 \\
0.51 \\
<0.02\end{array}$ & & $\begin{array}{r}5.8 \\
1.07 \\
<0.01\end{array}$ & & $\begin{array}{r}8.0 \\
1.30 \\
<0.01\end{array}$ \\
\hline
\end{tabular}

(Table I). The average difference between esophageal pressures measured during control periods and during drug infusion was zero. Right atrial pressure, however, fell during isoproterenol administration in each experiment. The average decrease was $1.9 \mathrm{~mm} . \mathrm{Hg}(\mathrm{p}<0.02)$. The transmural right atrial pressure also fell in each experiment. The average decrease was $1.9 \mathrm{~mm}$. $\mathrm{Hg}$ $(p<0.02)$. The fall in transmural pressure resulted from the fall in right atrial pressure since esophageal pressure was essentially unchanged.

Forearm venous responses to isoproterenol infusion

Forearm venous pressure fell in four and remained unchanged in one of five experiments during isoproterenol infusion (Table II). The average change was $1.8 \mathrm{~mm}$. Hg ( $<<0.05)$. Venous distensibility (the venous volume at a transmural venous pressure of $30 \mathrm{~mm} . \mathrm{Hg}$ ) decreased in each of the five tests. The average decrease was $1.5 \mathrm{ml}$. per $100 \mathrm{ml}$. of forearm tissue $(p<0.001)$. The naturally occurring forearm venous volume averaged $3.8 \mathrm{ml}$. per $100 \mathrm{ml}$. during control periods and fell to an average of $2.2 \mathrm{ml}$. per $100 \mathrm{ml}$. during isoproterenol infusion. This shift of blood from the extremity averaged $1.5 \mathrm{ml}$. per $100 \mathrm{ml}$. or 39.5 per cent of the average control value $(p<$ 0.001 ). The amount of blood pushed from the forearm by venous constriction alone averaged $1.3 \mathrm{ml}$. per $100 \mathrm{ml}$. or 34.2 per cent of the control value $(p<0.001)$. The amount which left the arm simply because of the fall in distending pressure averaged $0.2 \mathrm{ml}$. per $100 \mathrm{ml}$. or 5.3 per cent of the control volume.

The changes in transmural right atrial pressure, venous distensibility and venous pressure were maintained as long as the infusions were con-

TABLE II

Forearm venous responses to isoproterenol infusion

\begin{tabular}{|c|c|c|c|c|c|c|c|}
\hline \multirow[b]{2}{*}{$\begin{array}{c}\text { Experi- } \\
\text { ment }\end{array}$} & \multicolumn{2}{|c|}{ Venous pressure } & \multicolumn{2}{|c|}{ Venous distensibility } & \multicolumn{3}{|c|}{ Venous volume } \\
\hline & Control & $\begin{array}{c}\text { Iso- } \\
\text { proterenol }\end{array}$ & Control & $\begin{array}{c}\text { Iso- } \\
\text { proterenol }\end{array}$ & Control & $\begin{array}{c}\text { Iso- } \\
\text { proterenol }\end{array}$ & $\begin{array}{c}\text { Iso- } \\
\text { proterenol* }\end{array}$ \\
\hline $\begin{array}{c}\text { no. } \\
1 \\
2 \\
3 \\
4 \\
5\end{array}$ & $\begin{array}{l}17.5 \\
22.5 \\
18.0 \\
20.0 \\
20.0\end{array}$ & $\begin{array}{r}H_{g} \\
16.0 \\
20.0 \\
16.0 \\
17.0 \\
20.0\end{array}$ & $\begin{array}{l}5.3^{m l} \\
5.1 \\
4.2 \\
3.5 \\
4.3\end{array}$ & $\begin{array}{r}0 \mathrm{ml} . \\
3.6 \\
3.4 \\
2.8 \\
2.2 \\
3.1\end{array}$ & $\begin{array}{l}4.0 \\
4.5 \\
3.4 \\
3.1 \\
3.8\end{array}$ & $\begin{array}{c}m l . / 100 m l \\
2.3 \\
2.8 \\
2.2 \\
1.5 \\
2.4\end{array}$ & $\begin{array}{l}2.5 \\
3.1 \\
2.4 \\
1.7 \\
2.4\end{array}$ \\
\hline $\begin{array}{l}\text { Mean difference } \\
\text { Standard error } \\
\text { Probability }\end{array}$ & & $\begin{array}{l}1.8 \\
0.51 \\
<0.05\end{array}$ & & $\begin{array}{c}1.5 \\
0.10 \\
<0.001\end{array}$ & & $\begin{array}{c}1.5 \\
0.10 \\
<0.001\end{array}$ & $\begin{array}{c}1.3 \\
0.09 \\
<0.001\end{array}$ \\
\hline
\end{tabular}

* Forearm venous volume which would have existed during isoproterenol infusion if there had been only venous constriction and no change in venous pressure. 
tinued. The infusion periods ranged from four to nine minutes.

\section{DISCUSSION}

In previous experiments (16) venous constriction occurred during voluntary hyperventilation. This suggests that the constriction observed in the present investigation also might be attributed to overbreathing. The venous constriction associated with isoproterenol, however, greatly exceeded that observed with voluntary hyperventilation despite greater ventilatory rates and larger reductions in end-expiratory $\mathrm{CO}_{2}$ tension in the earlier experiments. The venous constriction seen with isoproterenol administration probably cannot be explained on the basis of hyperventilation alone.

If the peripheral venous constriction observed in these experiments were generalized the net result would be a shift of blood centrally. There is some support for this suggestion in the work of Bruce, Cobb, Katsura and Morledge (17) who reported increases in central blood volume with isoproterenol infusion in certain patients. A central shift of blood might seem inconsistent with the fall in transmural atrial pressure which we observed. The pressure in the central venous system, which may be considered a direct extension of the atrium, however, depends not only upon the volume of blood within it but also on the tonic state of its walls. If isoproterenol causes increased distensibility or reduced tone of the central veins the pressure could be low even though the volume were large.

The presence of increased cardiac output during isoproterenol administration $(1,18)$ might appear inconsistent with the decreased mean transmural atrial pressure if one accepts this parameter as an index of ventricular filling pressure. Sarnoff's concept of "a family of ventricular function curves" (19) seems useful in explaining the situation. According to his view increased stroke work in the presence of reduced filling pressure is still compatible with the Starling relationship between atrial pressure and cardiac output. The relationship is simply shifted to a higher curve, i.e., a level of function which yields more stroke work for a given pressure. This appears to occur with epinephrine (19) and it might occur with isoproterenol. A shift to a higher curve with these agents might result from increased contractility (leading to greater systolic emptying) or greater diastolic distensibility of the myocardium. In either case ventricular filling could increase even though filling pressure fell. The concept of increased myocardial distensibility has considerable support from intact dog (20) and isolated heart (21) experiments in the case of epinephrine whose other actions on the myocardium are similar to those of isoproterenol (5).

These experiments show that venous constriction shifts blood from the periphery and that transmural atrial pressure falls with isoproterenol. Despite this apparent paradox the fall in transmural pressure does not exclude a central shift of blood from consideration as an important determinant of the increased cardiac output. It tends to reinforce the thesis (1) that the action of isoproterenol on the myocardium does something to cause output to increase.

\section{SUMMARY}

Right atrial, intrapleural (esophageal) and transmural right atrial pressure were recorded simultaneously along with end-expiratory $\mathrm{CO}_{2}$ concentration before and during intravenous infusion of isoproterenol. Ventilation was measured intermittently. Despite the mild hyperventilation which occurred in each experiment, intrapleural pressure changes were not significant. Atrial pressure fell regularly as did the transmural pressure. The fall in transmural pressure was caused by the fall in atrial pressure because intrapleural pressure was not changed appreciably. The fall in atrial pressure previously observed (3) probably is not a ventilatory effect.

In other experiments forearm venous distensibility and pressure were measured before and during isoproterenol infusion into a foot vein. Venous pressure fell in most tests but venous constriction occurred regularly. The large shift of blood from the forearm which occurred in these experiments was caused primarily by the venous constriction and not by the fall in intraluminal pressure.

\section{REFERENCES}

1. Warren, J. V., Weissler, A. M., and Leonard, J. J. Observations on the determinants of the cardiac output. Trans. Ass. Amer. Phycns 1957, 70, 268. 
2. Altschule, M. D. Discussion: Observations on the determinants of the cardiac output. Trans. Ass. Amer. Phycns 1957, 70, 274.

3. Warren, J. V. Discussion: Observations on the determinants of the cardiac output. Trans. Ass. Amer. Phycns 1957, 70, 274.

4. Eckstein, J. W., and Hamilton, W. K. Changes in transmural central venous pressure in man during hyperventilation. J. clin. Invest. 1958, 37, 1537.

5. Goodman, L. S., and Gilman, A. The Pharmacological Basis of Therapeutics, 2nd ed. New York, The Macmillan Co., 1955, pp. 533-534.

6. Whelan, R. F., and Young, I. M. The effect of adrenaline and noradrenaline infusions on respirations in man. Brit. J. Pharmacol. 1953, 8, 98.

7. Eckstein, J. W., and Hamilton, W. K. The pressurevolume responses of human forearm veins during epinephrine and norepinephrine infusions. J. clin. Invest. 1957, 36, 1663.

8. Gauer, O. H., and Sieker, H. O. The continuous recording of central venous pressure changes from an arm vein. Circulat. Res. 1956, 4, 74.

9. Cherniak, R. M., Farhi, L. E., Armstrong, B. W., and Proctor, D. F. A comparison of esophageal and intrapleural pressure in man. J. appl. Physiol. 1955, 8, 203.

10. Worton, E. W., and Bedell, G. N. Determination of vital capacity and maximal breathing capacity: Simple, inexpensive method for use in normal subjects and in patients with lung disease. J. Amer. med. Ass. 1957, 165, 1652.

11. Wood, J. E., and Eckstein, J. W. A tandem forearm plethysmograph for study of acute response of the peripheral veins of man: The effect of environmental and local temperature change, and the ef- fect of pooling blood in the extremities. J. clin. Invest. 1958, 37, 41.

12. Litter, J., and Wood, J. E., The venous pressurevolume curve of the human leg measured in vivo (abstract). J. clin. Invest. 1954, 33, 953.

13. Wood, J. E., Litter, J., and Wilkins, R. W. Peripheral venoconstriction in human congestive heart failure. Circulation 1956, 13, 524.

14. Cooper, K. E., and Kerslake, D. McK. An electrical volume recorder for use with plethysmographs (abstract). J. Physiol. (Lond.) 1951, 114, 1 P.

15. Fisher, R. A. Statistical Methods for Research Workers, 10th ed. Edinburgh, Oliver and Boyd, Ltd., 1946.

16. Eckstein, J. W., Hamilton, W. K., and McCammond, J. M. Pressure-volume changes in the forearm veins of man during hyperventilation. J. clin. Invest. 1958, 37, 956.

17. Bruce, R. A., Cobb, L. A., Katsura, S., and Morledge, J. Comparative hemodynamic effects of isoproterenol and exercise (walking) in cardiac patients (abstract). J. clin. Invest. 1958, 37, 881.

18. Kaufman, J., Iglauer, A., and Herwitz, G. K. Effect of Isuprel (isopropylepinephrine) on circulation of normal man. Amer. J. Med. 1951, 11, 442.

19. Sarnoff, S. J. Myocardial contractility as described by ventricular function curves; observations on Starling's law of the heart. Physiol. Rev. 1955, 35, 107.

20. Rushmer, R. F., and Thal, N. Factors influencing stroke volume: A cinefluorographic study of angiocardiography. Amer. J. Physiol. 1952, 168, 509.

21. Opdyke, D. F. Effect of changes in initial tension, initial volume and epinephrine on ventricular relaxation process. Amer. J. Physiol. 1952, 169, 403. 